\title{
The Defective Transposition Of Directive 29/2005/EC On Unfair Trade Practices ${ }^{1}$ To Spanish Law
}

\author{
$\mathrm{M}^{\mathrm{a}}$ Ángeles Zurilla-Cariñana, Ph.D., University of Castilla-La Mancha, Spain
}

\begin{abstract}
Directive 29/2005/EC aims at the approximation of the regulations of Member States as regards unfair trade practices, including unlawful advertising. The transposition of this Directive to the Spanish legal system was made by means of 29/2009 Act. This Act reformed a number of laws including the Unfair Competition Act and the Consolidated Text of the General Act for the Defence of Consumers and Users. The classification of conduct that is forbidden in consumer Law, as regards unfair trade practices, is made directly by the state legislative, based on its exclusive responsibility regulating Commercial Law, and specifically, through the Unfair Competition Act, to which the whole of the CTGADCU (Consolidated Text of the General Act for the Defence of Consumers and Users) refers. The reasoning behind this option of the legislative is clear: to prevent the Autonomous Regions from enforcing regulatory control over the development of the protection of consumers and users. Nevertheless, the complexity of the system for the transposition of the Directive by 29/2009 Act gives rise to truly paradoxical situations: the detailed analysis of inconsistencies involved in the transposition method used for the Directive is the main focus of this work.
\end{abstract}

Keywords: Right to Information; Unfair Trade Practices; Deceptive Trade Practices; Deceptive Omissions

\section{INTRODUCTION}

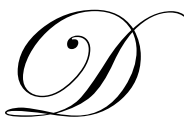

irective 2005/29/EC, of the May 11, establishes one of its main objectives as being the approximation of the laws of Member States regarding unfair trade practices, including unlawful advertising, which is also viewed as an unfair trade practice. It deals with trade practices with a direct influence on the decisions of consumers in transactions related to products, and makes a prohibition of a general nature of unfair practices that distort economic behaviour. This general prohibition is implemented by means of regulations for the two most common types of clauses included in these transactions: deceptive and aggressive clauses.

The types of unfairness described in the Directive constitute maximum regulations that cannot be exceeded or carried out by member states, where there are no unfair trade practices other than those included in the Directive itself, and neither are there other types of conduct prohibited in relations with consumers, apart from those worthy of being described as unfair trade practices (in view of 9,14,15, section 1.5). The States can enforce additional prohibitions to those set out in the Directive only for reasons of "good taste or decency", and not for other different reasons (in view of 7). They can also maintain or add information requirements related to Contractual Law and to repercussions in the domain of Contractual Law, if authorized by the minimum regulations of community Law, in order to guarantee a higher level of protection for the individual contractual rights of consumers (in view of 15). The

\footnotetext{
${ }^{1}$ This work is part of the Research Project entitled: "Regional impact of recent regulations for the rights of consumers: the arbitration regime and consumer mediation, the Consolidated Text of the General Law for the Defence of Consumers and Users and Directive 29/2005, on Unfair Trade Practices”. Reference: PPII 10-0199-9522.
} 
SCJECs (Sentences of the Court of Justice of the European Community) of April 23, 2009 and the January 14, 2010 clearly show the maximum nature of this Directive. It is therefore interesting that in our Law concerning this area, the Sentence of the Constitutional Court of the May 4, 2009 declares the temporary limitation of promotional discounts set out in the Trade Act of Cantabria to be unconstitutional.

29/2009 Act, of the December 30, transposes Directive 2005/29/EC to our legal system by modifying the legal regime for unfair competition and advertising in order to improve the protection of consumers and users. The transposition of this consumer Directive has been completed by means of an in-depth modification to a regulation of private Law: the Unfair Competition Act (hereinafter UCA), which gives rise to major imbalances and difficulties in interpretation, alongside other circumstances analyzed below. Other regulations are also subject to major reforms (cf. the Retail Commerce Act of 1996). For the purposes of this work, I will basically focus on regulations referred to in the above-mentioned UCA and to the Consolidated Text of the General Act for the Defence of Consumers and Users (hereinafter CTGADCU).

The goal of the modification of the CTGADCU is to clearly establish (as explained by the Preamble to 29/2009 Act) that in accordance with the pre-eminence of Community Law, the trade practices of business people aimed at consumers are governed solely by what is laid down in the Unfair Competition Act and the Consolidated Text itself, where there is no possibility of imposing other obligations, demands or prohibitions on the business people, other than those included in these regulations, when the rights being merged concern the protection of the legitimate interests of consumers. The CTGADCU contains three exceptions to this rule: specific regulations stipulated for reasons external to the protection of the legitimate interests of the consumers - those concerning the health and safety of consumers, including the security of goods or services -; specific regulations governing trade practices in laws that are a direct transposition of specific Community Directives stipulated in the domain of consumer protection; and the most protective stipulations that could be stipulated in the area of financial services or real estate (cf. art, 19).

As a consequence, following the reform, the classification of conduct prohibited in Consumer Law, as regards unfair trade practices, is made directly by the state legislative, based on its exclusive responsibility in regulating Commercial Law, specifically, by means of the UCA, which the CTGADCU refers to in full. The reasoning behind this option of the legislative is clear: this is the only way to prevent the Autonomous Regions from enforcing regulatory control over the development of the protection of consumers and users.

In Spanish law this goal is not entirely clear however, as we shall see in the pages below, because its transposition has been made in a very complex manner in this country, giving rise to major difficulties in terms of interpretation, since there are cross references between the UCA and the CTGADCU, which result in confusion on numerous occasions, and even perplexity.

We will also analyze how the right to information of consumers is approached in these laws and the impact they have, along with the Directive itself, on regulations for the protection of consumers in the Autonomous Regions.

\section{UNFAIR TRADE PRACTICES AND CONSUMER INFORMATION RIGHTS IN THE UNFAIR COMPETITION ACT AND THE CONSOLIDATED TEXT OF THE GENERAL ACT FOR THE DEFENCE OF CONSUMERS AND USERS}

Section 4 of the UCA, subsequent to the draft provided by 29/2009 Act, limits the general clause for unfairness in relations with consumers, where any behaviour objectively in conflict with the demands of good faith is considered unfair. Behaviour contrary to professional procedures is viewed as contrary to this principle, when it significantly (fundamentally) distorts or could distort the behaviour of average consumers or normal members of the target group of the practice (if it is aimed at a specific group of consumers). Such a distortion is understood to occur when the ability of the consumer to take fully-informed decisions is substantially reduced, so they end up taking other decisions they would not otherwise take. Deceptive information or the omission of this information is essential for this purpose. 
The general clause on unfairness in section 4 of the UCA is exhausted in the event of sections 5 to 8 and sections 20 to 31 of the UCA. This means other residual prohibitions for unfair conduct cannot be established, when they are not envisaged in the implementation rules.

Inherent in the description of trade practices as unfair and of omissions as deceptive in the UCA following the reform, is the basic assumption of untrue information (section 5) or its concealment, when full and clear information is required to take appropriate decisions (section 7).

Similarly, the UCA views deceptive trade practices as those containing false information, which could alter the behaviour of consumers, or information, which while being true, leads or may lead to errors as regards any of the elements or limits it refers to and affects in any of these areas (stocks of the good or service; its main characteristics; after-sales service for the client and the processing of claims; the scope of the commitment of the business person or professional; the price or way in which it is set; the need for a service or part, replacement or repair; the legal or conventional rights of the consumer or risks they may be running), -section 5-.

Deceptive omissions are described as the omission or concealment of information required so the target audience can take properly informed decisions concerning their economic behaviour. Unclear, unintelligible or ambiguous information, or information not provided at the correct moment, or the commercial goal of which is not given, unless it can be garnered from the context, is considered unfair because it is deceptive. This should be taken into account for determining the deceptive nature of the act (section 7 UCA). The omission of information is only considered deceptive when the circumstances laid down by this rule concur. The mere omission of information does not in principle constitute a deceptive trade practice.

Trade practices are also considered to be deceptive when they are aggressive. Section 8 of the UCA views as unfair any kind of behaviour, which in regard to its characteristics and circumstances, is susceptible to significantly reducing, through harassment, coercion, including the use of force, or undue influence, the freedom of choice or conduct of the target audience of the goods or services, and which as a result, affects or could affect their economic behaviour. For these purposes, undue influence is considered to be use of a position of power in relation to the target audience of the practice to exert pressure, even without the use of physical force or threats in its use.

The new section 20 of the CTGADCU lays out the information required that the consumer or user must receive. It sets up the minimum contents of positive trade information in trade practices, which must include information on the characteristics of the good or service. In accordance with this rule, the practices must contain, if this is not clear from the context, at least the following information: commercial name, the essential characteristics of the good or service in a way suited to its features and the communication method used; the complete final price, including taxes, increases and discounts that can be applied, and additional expenses passed on to the consumer or user; if the price cannot be set exactly, at least the basis used for the calculation to enable the purchaser to check the price; the payment procedures, deadlines for delivery and execution of the contract; the system for processing claims; and when appropriate, the existence of a right of withdrawal (section 20. 1). Non-fulfilment of the contents of this section is viewed at all times as unfair practice by deception.

A comparison between this rule and section 5 of the UCA highlights the conflict between them:

The omission of information required by virtue of section 20 of the CTGADCU constitutes unfair competition by deception, as explained above. Nevertheless, according to section 5 of the UCA, the deceptive information only constitutes unfair competition when it affects the elements mentioned therein, which are additional to the limits on the information that must be supplied to consumers. This is important because these elements, insofar as they go beyond section 20, do not necessarily have to appear in the information the consumer is provided with, but if provided, constitute acts of unfair competition if they are deceptive.

The lack of consistency in Spanish legislation is greater still when comparing section 20 of the CTGADCU with section 7 of the UCA. As we have seen the basic regime for deceptive omissions of article 7 of the Directive is formulated here, but details are not provided on the information that has to be supplied of a fundamental nature. Section 20 does this, as we have seen, by reproducing fairly closely the list of the Directive. However, worthy of 
note is the fact that the list contained in this section is not closed, since it establishes that the trade practices it refers to shall contain, at least, the information listed.

This begs the question of whether the implementation rules can impose specific obligations regarding information before and on the occasion of a sales offer, or whether they have to be limited to repeating the mandate of the above-mentioned article 7 of the Directive. I feel the response must be affirmative, with the clarifications made in the following section, and these specific obligations can be imposed. This regulation is however, only admissible if the information it refers to is fundamental and determinant for the purchase obligation, according to the meaning of the Directive. It will be necessary therefore, to carry out am individualized adjustment of the implementation rule when it imposes duties of this kind.

Whatever the case may be, we should not lose sight of the fact that, as explained in the introduction, the objective of the Directive is to prevent the unconditional imposition of duties to provide information on the business people involved, but not to limit the jurisdiction of States to impose specific contractual duties. What legislators cannot do is to make the information referring to these duties compulsory, unless the information is fundamental and decisive to the conclusion of the contract, as required by the Directive.

\section{IMPACT OF DIRECTIVE 2005/29 ON THE CONSUMER LAWS OF THE AUTONOMOUS REGIONS}

The importance of the information rights of consumers has led to an abundance of regulations in this area, on state and regional levels, resulting in duties to provide information for business people as regards the goods and services they offer. Directive 2005/29 and its transposition to our legal system considers the two above-mentioned questions: regarding the jurisdiction of the Autonomous Governments to establish duties to provide information and regarding the extent to which the Directive will be affected.

As we mentioned in the previous section, the UCA, following the reform made by 29/2009 Act, classifies unlawful conduct concerning unfair trade practices. It does this based on the exclusive jurisdiction of the state legislative to regulate trade Law. As a consequence, the Autonomous Governments cannot classify or prohibit unfair trade practices, or impose duties to provide information on the basis of the exclusive jurisdiction for the regulation of the regime for the protection of consumers or domestic trade.

Nevertheless, the complexity of the system for the transposition of the Directive by 29/2009 Act results in truly paradoxical situations: The Second Final Provision point 3 of 29/2009 Act, defines sections 19 and 20 of the CTGADCU as basic, or in other words, subject to being developed by the Autonomous Regions. As a result, a regional regulation making trade contents in excess of those contained in section 20 compulsory would not violate the state regulation. Firstly, because it is basic and not exclusive. Secondly, because section 20 is not exhaustive (it employs the phrase "at least"). This regional regulation, which is not in opposition to the state regulation, would however violate article 7.4 of the Directive.

This result may cause perplexity but is unanswerable: sections 19 and 20, in their current form, do not abolish or oblige the Autonomous Governments to abolish any implementation regulations concerning those mentioned, which must be included in the compulsory information to be supplied by the business people in trade practices with consumers.

The Autonomous Regions are clearly not bound by the Directives, and these do not constitute an imposition except through the state legislation that implements them, until the ECJ passes sentences on possible conflicts between state and community Law. Despite this, I am of the opinion that information should not exceed in its contents from that which is set out in section 20. 1, purely as a result of logical legal reasoning.

Whatever the case may be, according to article 3.5 of the Directive, any regional regulation, which has developed regulations of the community consumer Directives with higher levels of protection than in the contents of these Directives, can be maintained until 2013. Consequently, until this date is reached, there is no problem for member States to continue applying these provisions. 
Despite exceeding in the remit of this work, I cannot avoid making a brief reference to questions related to the legal authority to impose penalties in this area.

Despite the fact that 29/2009 Act does not define the authorities with jurisdiction to impose penalties on unfair trade practices, these will doubtless be the regional authorities. That is the case for section 49 of the CTGADCU, which following the reform of 2009, adds a section 1 , which views the use of unfair trade practices with consumers as infractions of the consumer regime. Its classification however, is made by means of reference to the UCA, which catalogues the unfair trade practices in question. This circumstance gives rise to a consequence that is a source or perplexity: consumers can also exercise the corresponding actions in the field of unfair competition before the commercial courts when they are directly affected (cf, section $33.1 \mathrm{UCA}$ ). The actions referred to are cessation, removal, rectification and compensation. This is the result of the regulation of unfair trade practices on dual fronts: the commercial regime for unfair competition and the administrative regime for the protection of consumers.

Lastly, we should not forget they can also carry out acts of compliance, invalidity, termination of contracts and compensation for damage and injury resulting from breach of contract in common jurisdiction and by means of common procedure. This is explained in section 19.2 of the CTGADCU, which in its new draft, establishes that "relations of a contractual nature are not to be considered unfair trade practices".

\section{CONCLUSIONS}

Directive 2005/29/EC on Unfair Trade Practices is a Directive of a maximum nature, where there are no other unfair trade practices, different to those set out by the Directive itself, or other forbidden conducts as regards relations with consumers apart from those worthy of being described as unfair trade practices (in view of 9,14,15, section 1.5).

Transposition to the Spanish legal system of Directive 2005/29/EC has been carried out in the Spanish legal framework by means of a defective legislative technique; through an in-depth modification, among others, of two regulations: the Unfair Competition Act and the CTGADCU.

The objective of the modification of the CTGADCU is to clearly establish (as described in the Preamble to 29/2009 Act, transposing the Spanish system to the Directive) that, in accordance with the pre-eminence of Community Law, the trade practices of business people aimed at consumers are governed solely by the contents of the Unfair Competition Act and the Consolidated Text itself, without there being any scope for the imposition of other obligations, demands or prohibitions on the business people and professionals other than those laid down in these regulations, where the right they give rise to is the protection of the legitimate interests of consumers.

Subsequent to the reform, the classification of prohibited conduct in Consumer Law, as regards unfair trade practices, is made directly by the state legislative, based on its exclusive jurisdiction for the regulation of Commercial Law, specifically, through the UCA, which the CTGADCU refers to in full.

Nevertheless, the complexity of the system for the transposition of the Directive by 29/2009 Act gives rise to truly paradoxical situations: the Second Final Provision point 3 of 29/2009 Act, defines sections 19 and 20 of the CTGADCU as basic, or in other words, susceptible to being developed by the Autonomous Governments. As a consequence, an autonomous regulation that was to impose trade contents in excess of the contents of section 20 would not violate state regulations. Firstly, because it is basic and not exclusive. Secondly, because section 20 is not exhaustive (it employs the term "at least"). This autonomous regulation, which is not contrary to state regulations, would however violate article 7.4 of the Directive.

\section{AUTHOR INFORMATION}

Ma Ángeles Zurilla Cariñana, Doctor in Law at the University of Castilla La Mancha, Professor in Civil Law at the Faculty of Social Sciences of Cuenca (University of Castilla La Mancha. Spain). E-mail: maria.zurilla@uclm.es

Research Interest: Research in the field of Contractual, Family, Inheritance and Consumer Law. 


\section{REFERENCES}

1. Avilés, J. (2009): “Contracts, information, guarantees and unfair trade practices”. Private Law Magazine, 93, 3-32.

2. Busto, J. M. (2009): "Comments on section 19" in "Comments on the Consolidated Text of the General Act for the Defence of Consumers and Users" (R. Bercovitz -Coordinator-). Aranzadi. Pamplona. 273-274.

3. Carrasco, A. (2009): "Modification of the regime for unfair competition and protection of consumers as regards unfair trade practices".

4. Cedó, M. and Colomer, G. (2006): "The Directive on Unfair Trade Practices”. Economist \&Jurist. Vol. 14, $104,18$.

5. $\quad$ Fernández, P. (2004): “Concealed advertising and product placement”. Cedam. Padova.

6. García, M. P (2009): “Unfair trade practices: A robust consumer protection?”. Aranzadi Doctrinal, 6, 127-158.

7. Leiñena, E. and Irákulis, N. (2007): "Illicit advertising and the study of Directive 2005/29/EC on unfair trade practices". Aranzadi Civil, 2, 2433-2463.

8. Marcos. F; Suñol and Masseguer, J (2006): “The transposition of Directive 2005/29/EC on unfair trade practices to the Spanish legal system”. Bulletin of Information of the Ministry of Justice, 2013, 1925-1963.

9. Massaguer, J. (2006): “The new Law against unfair competition”. Civitas. Madrid

10. Palau, F. (2010): "On the compatibility of trade regulations and the protection of consumers under the Directive for Unfair Trade Practices or the pending adaptation". Law Magazine on competition and distribution, 7, 174-214.

11. Tamayo, J. A. (2006): “Trade and consumer practices (for the purposes of Directive 29/2005/EC, of the $11^{\text {th }}$ of May, on unfair trade practices". European Union News, 263, 59-70.

12. Tato, Fernández and Herrera (2010): "The reform of the Unfair Competition Act". THE LAW. Madrid.

13. Zurilla, M. A. (2010): "Are the trade laws of the Autonomous Regions in agreement with the Directive on Unfair Trade Practices? The example of Castilla La Mancha. Directive on Unfair Trade Practices". www.uclm.es/centro/cesco 